\title{
Development of Village Applicant Capacity Training Model Based on Village Information System in Village Community Empowerment Department in Langkat District
}

\author{
Robinson Hutagaol ${ }^{1}$, Abdul Hasan Saragih ${ }^{2}$, Sahat Siagian ${ }^{3}$ \\ ${ }^{1}$ Dinas Pendidikan dan Olahraga Sumatera Utara, Indonesia \\ ${ }^{2,3}$ Faculty of Engineering, Universitas Negeri Medan, Indonesia \\ Email: rhgaol9@gmail.com
}

\begin{abstract}
:
This study aims to: (1) produce an Addcie model for training the capacity of village apparatus based on village information systems, which is suitable for use in training the capacity of village officials (2) to determine the effectiveness of the Addcie model for training the capacity of village officials based on the village information system. This type of research is research and development using the $R \mathcal{E} D$ model from Borg and Gall combined with the instructional design model from Dick and Carey. The research method consists of two stages, namely stage I developing a training learning model and conducting trials, and stage II conducting product effectiveness testing. In the development and testing stage the product must go through a series of validation and trial processes. The results showed that (1) the material expert's assessment was very good, (82.94\%), (2) the learning design expert's assessment was very good (81.58\%), (3) the expert assessment of the learning model was on very good criteria $(94.42 \%)$, (4) the assessment of media experts is in very good criteria (85\%), (5) the assessment of individual trials is in very good criteria (81.03\%), (6) assessment of small group trials is also in very good criteria $(90.09 \%)$, (7) the assessment of limited field trials which are in very good criteria (92.08\%).
\end{abstract}

\section{Keywords:}

learning model; apparatus capacity training; information system

\section{Introduction}

The dynamic development of rural villagers supported by the higher level of education, knowledge, information, communication technology and skills demands professionalism from village officials to increase capacity, capacity and quality of services for the community. The village apparatus is the government's lowest implementer. In carrying out their duties and functions, they must be able to demonstrate their quality as a servant of the state and a servant of society. As a community servant, the village apparatus is a representative of the community with this dual function, it is hoped that the village apparatus will be able to represent the community they lead. The Village Government under the leadership of the Village Head has the following tasks: (1) to efficiently and accountably carry out government, development and community affairs, (2) to carry out government affairs delegated by the Regent.

According to Angelia at al, (2020) In a matter of statistical figures it is often mentioned that the inhabitants of this country with the largest percentage (more than 60 percent) live in rural areas. The dimension of developing a capacity training model is the ability of village officials to produce villages which are the ideals of the government in order to improve village government and community services, so by training the capacity of village government officials based on the Village Information System at the Village Community Empowerment Service in 
Langkat Regency. According to Matrozet and Nurwani (2019) Obeying norms and upholding values is very important for the community itself in preserving cultural and social life.

Culture is a habit that occurs repeatedly in human life, as well as one of the main elements in community development in the life of the nation and state. Village is a legal community unit that has an original arrangement based on special original rights (Nuraflah, 2020). The training model for village apparatus has been using the deductive/conventional model, which means that direct training to training participants and at the same time the delivery of material is still transparent paper using an overhad, flipchart paper followed by a lecture method from the facilitator which runs in one direction and quickly becomes boring, making many participants sleepy. Therefore, the village needs completely new methods, this will be developed with a system called Village Information System technical administrative foundation article 86 of the 2014 Village Law Development of Rural Areas, says (1)Village has the right to access information through a village information system developed by the Regency/City Government, (2)The Government and Regional Government are required to develop a village information system and rural area development, (3)the village information system as referred to in paragraph 2 includes hardware facilities and software, networks, and human resources, (4)The village information system as referred to in paragraph 2 , includes village data, village development data, rural areas, as well as other information related to village development and regional development. (5)the village information system as referred to in article 2, managed by the government intah village and can be accessed by the village community and all stakeholders. (6)The district/city government provides information on district/city development planning for the village, so it can be said to be village data or data information systems in the village.

To focus more on observations and plans on the researcher's plan on the conditions of training the capacity of village government officials based on village information systems that can support the duties and functions of village heads, village secretaries and village officials in improving service performance to village communities, the researcher wants to examine research development of training models village apparatus capacity building based on the village information system application using the Dick and Carey product development model. This training product development model is a model that is programmed in a systematic order and fulfills the characteristics of the training participants in learning.

This application is a technical guide at the village level and is intended for village officials or village teams that will run the village information system. The presence of a village information system to make all information systems uniform in the village. The Village Information System contributes to the process of integration and synergy of the data collection system in the village. The spirit carried by the village information system is, One data 'in one application. To complement the implementation of the training, a survey and interview were carried out for administrative completeness of the implementation of the Model Development (ADDCIE) Training for Village Apparatus Capacity Training, Analysis, Design, Development, Coundact, Implementation, Evaluation) based on Village Information Systems at the Community and Village Empowerment Service in the District Leave.

\section{Research Methods}

This research uses the Research and Development ( $\&$ D) method, because the research product offered is in the form of developing a model for training the capacity of village apparatus based on village information systems in learning village apparatus capacity 
training, Gall and Borg (2003: 569) say that development research is characterized by the presence of products. And research procedures that can be systematically tested in the field, validated/ evaluated, and improved until the resulting product meets several of the above criteria is feasible, effective and has standard standards.

The steps that must be taken in carrying out research and development according to Gall and Borg (2003: 626) include (1) Research and information collecting, (2) planning, (3) develop prelimary form of product, (4) preliminary field testing, (5) main product revision, (6) main field testing, (7) operational product revision, (8) operational field testing, (9) final product revision, (10) dissemination and distribution.

The R\&D model from Borg and Gall above serves as a reference in the implementation of this research and development. Therefore, operationally the steps taken in this research and development are as follows:

1. Conducted a preliminary study.

2. Developing a dissertation research design based on the initial framework.

3. Develop research instruments.

4. Developing a learning model for training materials.

5. Validating the training learning model.

6. Revised the learning model.

7. Conducting trials of learning models.

8. Revise the village information system.

9. Completion of the final product stage.

10. The implementation stage of the learning model.

11. Compilation of research reports, as the end of research and development activities. 


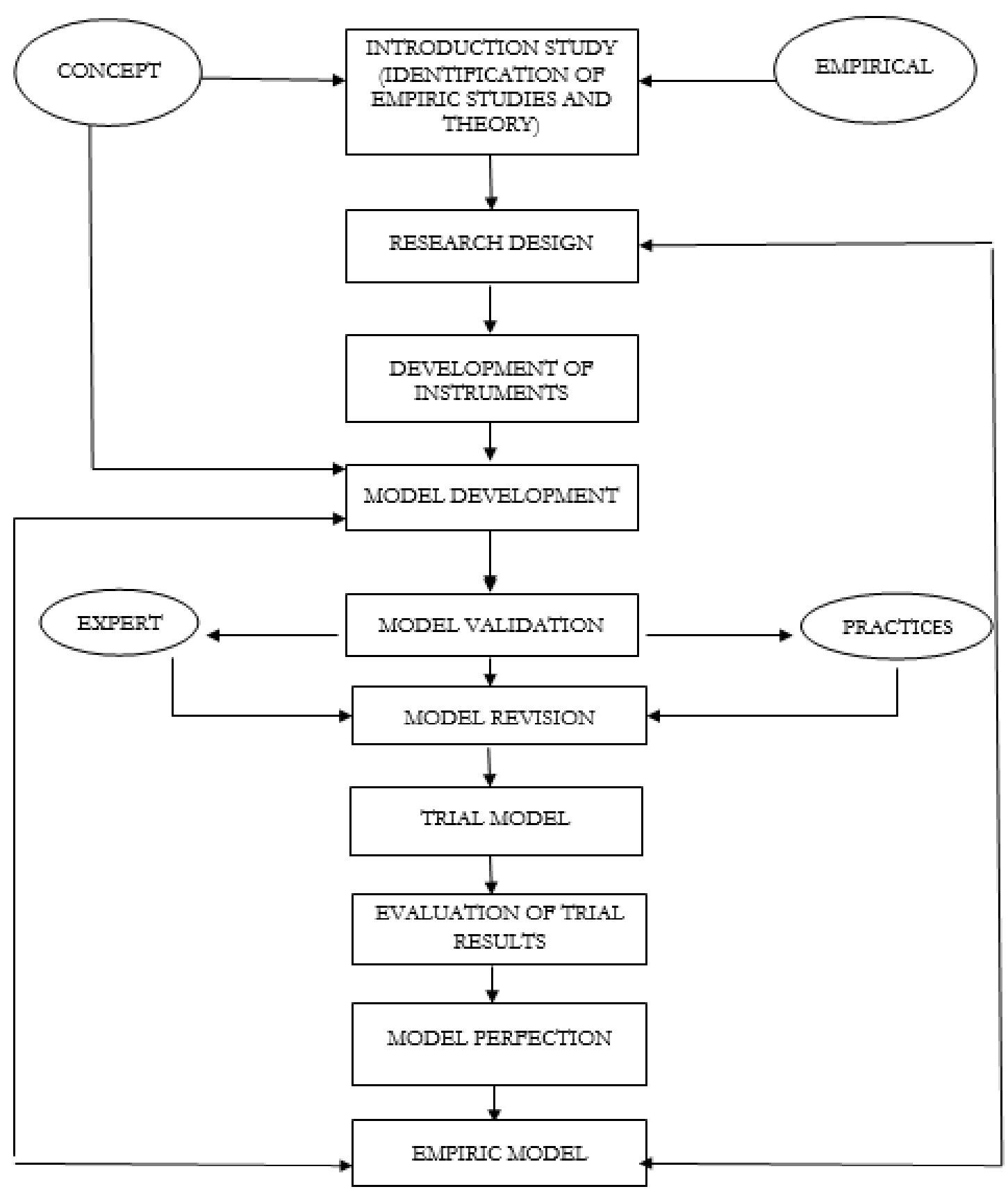

Figure 1. Terms of Reference for Research Activities

\section{Discussion}

\subsection{Initial Product Development Process}

The result of this initial product development process is in the form of a learning model for training the capacity of village apparatus based on the village information system called ADDCIE and its supporting system in the form of teaching modules, participant manuals, facilitator manuals and ADDCIE Model books. The development product is intended for training participants at the Village Community Empowerment Service in Langkat Regency. The material contained in the module is aimed at the Village Community Empowerment Service in Langkat Regency at the Village Community Empowerment Service in Langkat Regency. The lesson training material is packaged in the form of teaching modules, videos, visuals and text. The description contained in the teaching module product, participant 
manual, facilitator's manual and ADDCIE model book is as follows:
1. Cover
2. Chapter
3. Facilitator Guidance
4. Competence
5. Content
6. Evaluation
7. Direction
8. Facilitator Book

\subsection{Description of Product Trial Result Data}

Testing of the learning model product developed was carried out in 15 stages, namely: (1) expert validation of learning materials, (2) expert validation of learning designs, (3) expert validation of learning models, (4) validation of media experts, (5) analysis data from the validation results of the three experts, (6) revision I, (7) individual trials, (8) analysis of data from individual trials, (9) revision II, (10) small group trials, (11) data analysis of test results small group trials, (12) revision III, (13) limited field trials, (14) data analysis of limited field trials, and (15) final products. Based on the product assessment through a series of trials and revisions that have been carried out, the learning model based on the village information system and its supporting systems is declared feasible.

\section{a. Learning Expert Validation Results Data}

Validation from model experts aims to determine the expert's opinion about the product of the learning model developed in terms of model construction which includes several aspects, namely: rational models, supporting theories and impact of application. This validation was carried out by one learning model expert, namely Prof. Dr. Harun Sitompul, M.Pd. The results of the validation from the expert in the form of an assessment score, there are aspects of the learning model in terms of model constructs with a value range of 1-5.

Table 1. Percentage of Model Expert Assessment Results on the Village Information System-Based Learning Model

\begin{tabular}{|c|c|c|c|}
\hline No & Assessment Indicators & Percentage & Criteria \\
\hline 1. & Rational Aspects of the Model & $100 \%$ & Very Good \\
\hline 2. & Supporting Theory Aspects of the Model & $100 \%$ & Very Good \\
\hline 3. & Aspects of Media Audio & $90 \%$ & Very Good \\
\hline 4. & Syntax Aspects & $91,11 \%$ & Very Good \\
\hline 5. & Social System Aspects & $93,33 \%$ & Very Good \\
\hline 6. & Principle Aspects of Reaction & $95 \%$ & Very Good \\
\hline 7. & Supporting System Aspects & $92,50 \%$ & Very Good \\
\hline 8. & Aspects of Impact Implementation & $95 \%$ & Very Good \\
\hline & Total & $94,42 \%$ & Very Good \\
\hline
\end{tabular}

From the table 1, it is known that the total percentage of model expert judgment from all aspects is $94.42 \%$ which is included in the "very good" assessment criteria. The results of the expert assessment of the village information system-based learning model can also be presented in the form of a diagram as shown in Figure 2: 
Presentation of Model Expert Assessment Results

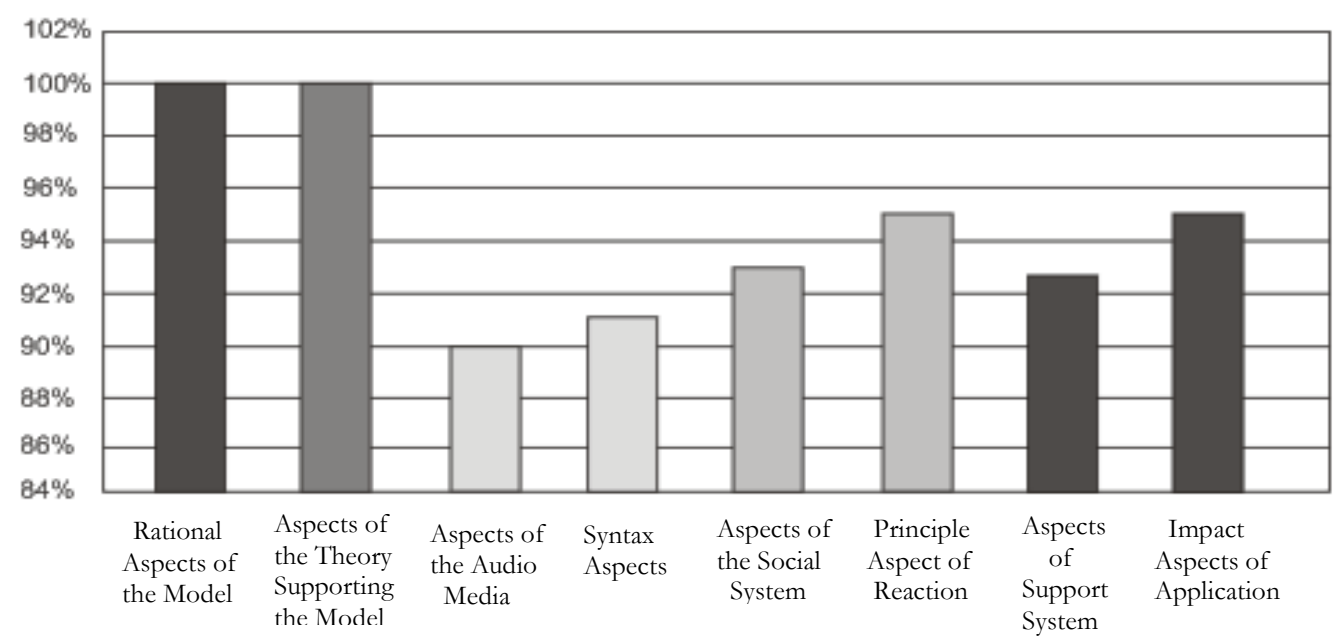

Figure 2. Bar chart of Model Expert Assessment Results on the Village Information System Learning Model

In addition to the assessment score, there are also some comments and suggestions from model experts for improving the use of this learning model. Based on the model expert's response, this village information system-based learning model is feasible to be tested on users (participants) with revisions according to the expert's suggestions and this model is generally accepted.

\section{b. Learning Material Validation Results Data}

The validation of this learning material expert aims to find out the expert's opinion about the product of the learning model developed in terms of content which includes several aspects, namely: the feasibility of content, presentation, language and competence.

Table 2. Percentage of Material Expert Assessment Results on Learning Models

\begin{tabular}{|c|l|c|c|}
\hline No & \multicolumn{1}{|c|}{ Assessment Indicators } & Percentage & Criteria \\
\hline 1. & Content Feasibility Aspects & $76,67 \%$ & Good \\
\hline 2. & Presentation Aspects & $83,33 \%$ & Very Good \\
\hline 3. & Linguistic Aspects & $86,67 \%$ & Very Good \\
\hline 4. & Graphic Aspects & $95 \%$ & Very Good \\
\hline & Total & $82,94 \%$ & Very Good \\
\hline
\end{tabular}

From Table 2, it is known that the percentage of material expert judgment from all aspects is $82.94 \%$ which is included in the very good assessment criteria. The results of the material expert's assessment of the village information system-based learning model can also be presented in the form of a bar chart as seen in the Figure 3: 
Presentation of Expert Assessment of Learning Material Results

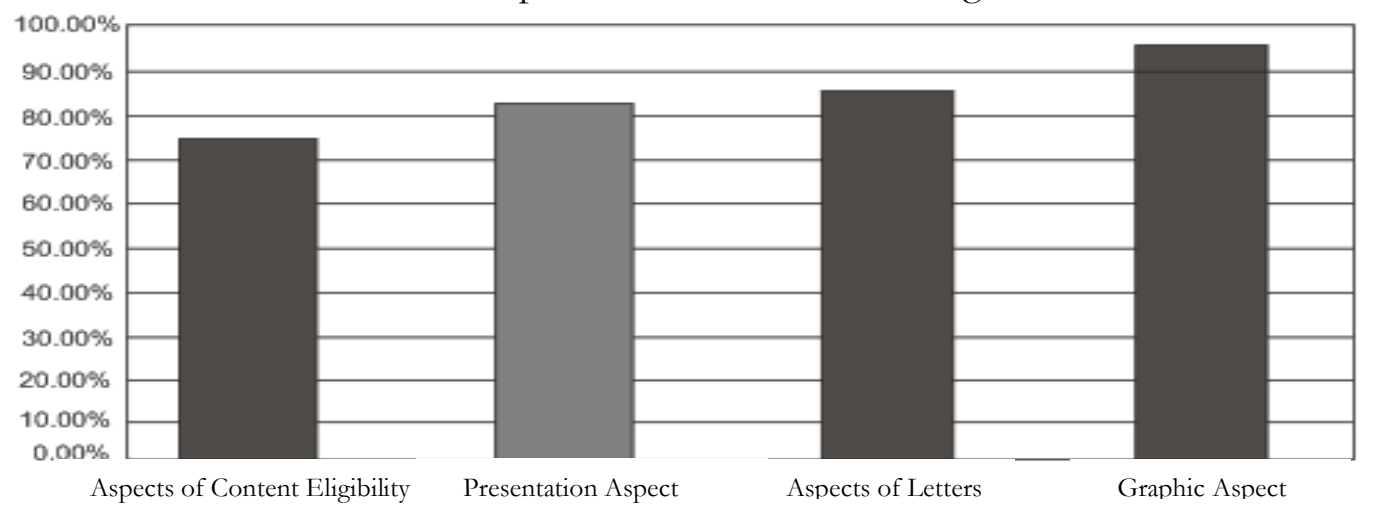

Figure 3. Diagram of the Results of Expert Assessment of Learning Materials on Learning Models

In addition to the assessment score, there are also some comments and suggestions from learning material experts to improve the use of this learning model. Based on the responses of learning material experts, this village information system-based learning model is feasible to be tested on this user and is generally accepted.

\section{c. Learning Design Validation Results Data}

The validation of the learning design expert aims to find out the expert's opinion about the product of the learning model developed in terms of instructional design which includes several aspects, namely: content feasibility, presentation and competence. This validation was carried out by the two learning design experts.

Table 3. Percentage of Design Expert Assessment Results Against Village Information System Based Learning Model

\begin{tabular}{|c|c|c|c|}
\hline $\mathrm{No}$ & Assessment Indicators & Percentage & Criteria \\
\hline 1. & Content Feasibility Aspects & $90 \%$ & Very Good \\
\hline 2. & Presentation Aspects & $81 \%$ & Very Good \\
\hline 3. & Graphic Aspects & $76 \%$ & Good \\
\hline & Total & $81,58 \%$ & Very Good \\
\hline
\end{tabular}

The results of the learning design expert's assessment of the village information system-based learning model can be presented in the form of a bar chart as shown in Figure 4:

Presentation of Learning Design Expert's Assessment Results

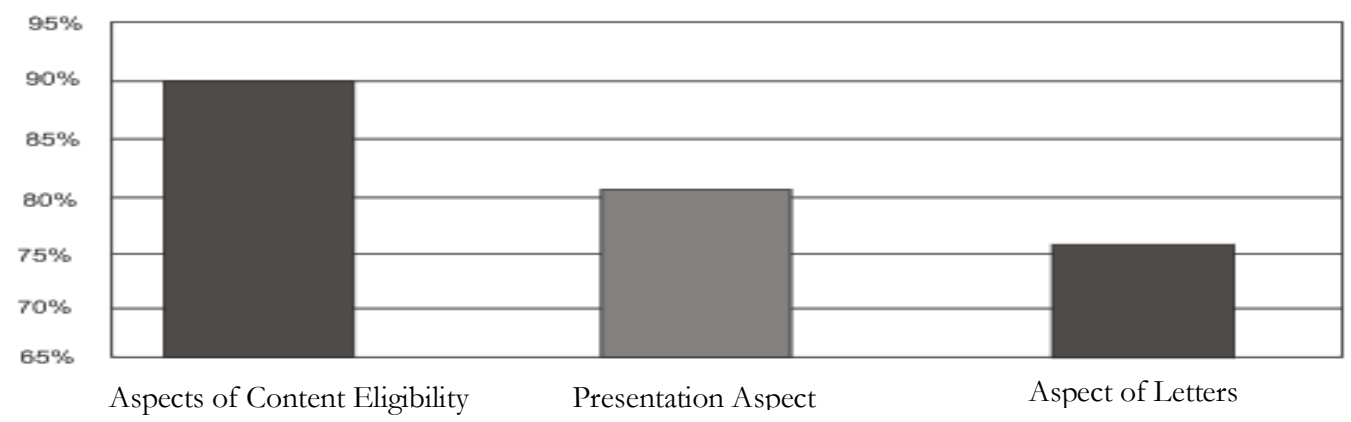

Figure 4. Bar Chart of Learning Design Expert Assessment Results Against Village Information System Based Learning Model 
In addition to the assessment score, there are also some comments and suggestions from learning design experts to improve the use of this learning model. Based on the response of the learning design expert, this village information system based learning model is feasible to be tested on users (participants) with revisions according to the suggestions proposed by the design expert and this model can be generally accepted.

\section{d. Data on Media Expert Validation Results}

Validation from media experts aims to find out the expert's opinion about learning module products developed in terms of media constructs that are integrated with village information system-based learning models which include several aspects, namely content appropriateness, presentation, and audio media.

Table 4. Percentage of Results of Media Expert's Assessment of Village Information System-Based Learning Model

\begin{tabular}{|c|l|c|c|}
\hline No & \multicolumn{1}{|c|}{ Assessment Indicators } & Percentage & Criteria \\
\hline 1. & Content Feasibility Aspects & $83,33 \%$ & Very Good \\
\hline 2. & Presentation Aspects & $84 \%$ & Very Good \\
\hline 3. & Aspects of Media Audio & $86,15 \%$ & Very Good \\
\hline & Total & $85 \%$ & Very Good \\
\hline
\end{tabular}

From table 4, it is known that the total percentage of media expert assessments from all aspects is $85 \%$ which is included in the "very good" assessment criteria. The results of the media expert's assessment of the village information system-based learning module can also be presented in the form of a bar chart as shown in Figure 5.

Media Assessment Expert Presentation

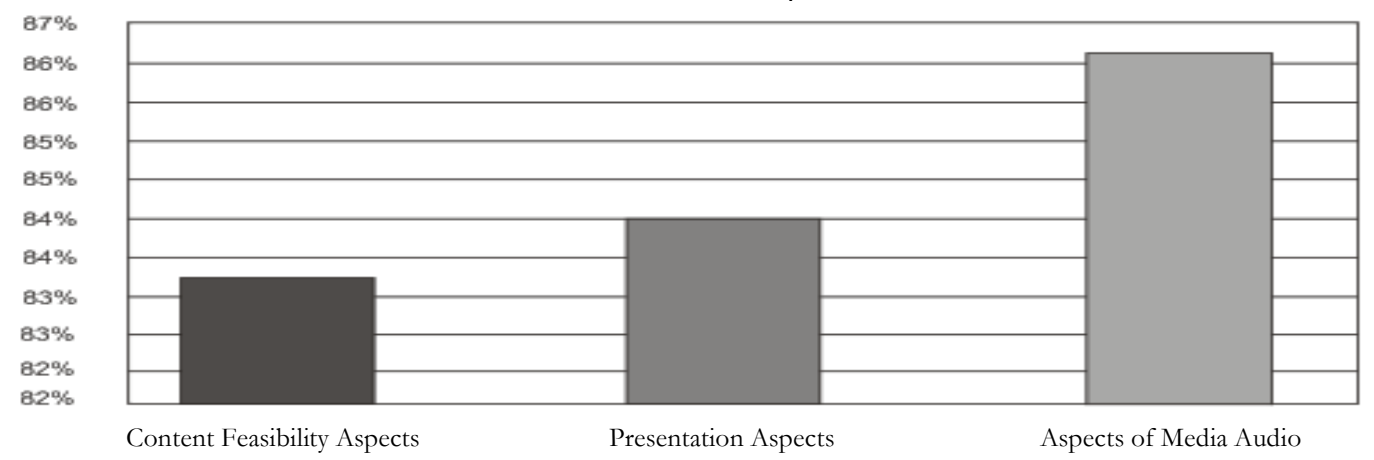

Figure 5. Bar diagram of the results of the media expert's assessment of the Village Information System-Based Learning Model

In addition to the assessment score, there are also some comments and suggestions from media experts for improving the use of this learning model. Based on ahlimedia's response, this village information system-based learning model is feasible to be tested on users (participants) with revisions according to the suggestions proposed by the media expert and this model can be generally accepted.

\section{e. Data on Individual Trial Results}

Individual trials were carried out in villages under the auspices of the Village Community Empowerment Service in Langkat Regency. The three villages consist of 1 village apparatus from the village of Kwala Begumit with high achievement, 1 person with moderate achievement, 1 person, and 1 village apparatus with low achievement. The purpose of this individual trial is to identify deficiencies in the Addcie learning model product based on the 
village information system that was developed after the validation stage from the experts.

Table 5. Percentage of Individual Trial Assessment Results on Village Information System Based Learning Model

\begin{tabular}{|c|l|c|c|}
\hline No & \multicolumn{1}{|c|}{ Assessment Indicators } & Percentage & Criteria \\
\hline 1. & Content Feasibility Aspects & $81,33 \%$ & Very Good \\
\hline 2. & Presentation Aspects & $80 \%$ & Very Good \\
\hline 3. & Linguistic Aspects & $73,33 \%$ & Very Good \\
\hline 4. & Graphic Aspects & $90 \%$ & Very Good \\
\hline & Total & $81,03 \%$ & Very Good \\
\hline
\end{tabular}

From Table 5, it is known that the total percentage of the assessment in individual trials from all aspects is $81.03 \%$ which is included in the assessment criteria "very good". Based on user responses (participants), this village information system-based learning model deserves to be continued in the next trial with revisions according to their proposed targets. The results of the assessment from these individual trials can also be presented in the form of stick digrams as shown in Figure 6 below:

Presentation of Individual Trial Assessment Results

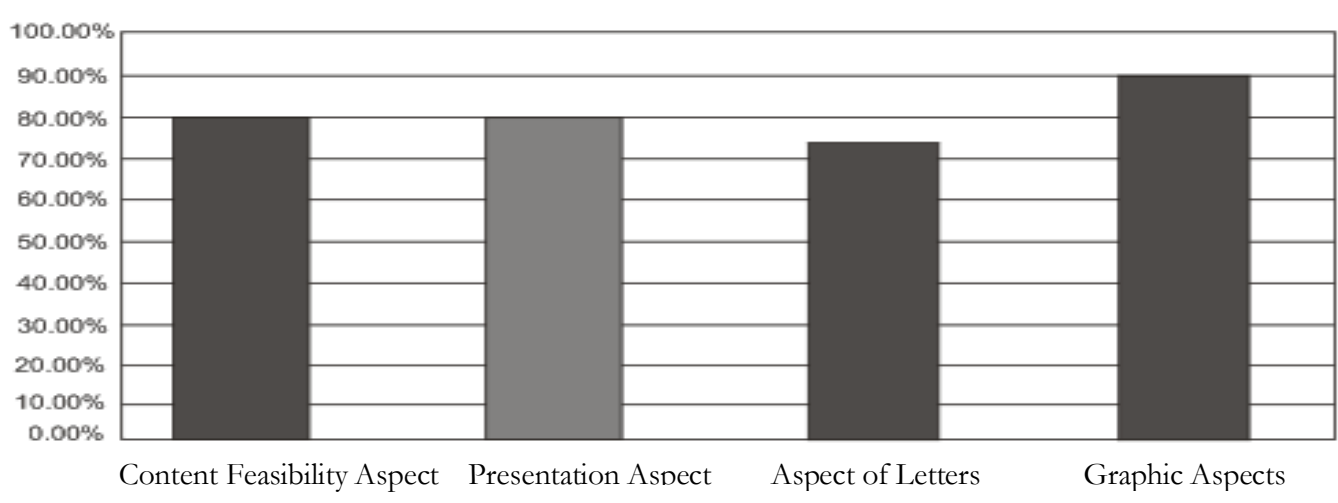

Figure 6. Bar Chart of the Results of Individual Trial Assessment of the Village Information System Based Learning Model

\section{f. Small Group Trial Result Data}

Small group trials were carried out in villages under the auspices of the Village Community Empowerment Service in Langkat Regency. From the village, there are 9 village officials from Cirurai Selatan village with high achievement, 3 people with moderate achievement, 3 people, and 3 village officials with low achievement. The purpose of this individual trial is to identify deficiencies in the Addcie learning model product based on the village information system that was developed after the validation stage from the experts.

Table 6. Percentage of Small Group Trial Assessment Results on Village Information System Based Learning Model

\begin{tabular}{|c|c|c|c|}
\hline $\mathrm{No}$ & Assessment Indicators & Percentage & Criteria \\
\hline 1. & Content Feasibility Aspects & $89,78 \%$ & Very Good \\
\hline 2. & Presentation Aspects & $85 \%$ & Very Good \\
\hline 3. & Linguistic Aspects & $94,44 \%$ & Very Good \\
\hline 4. & Graphic Aspects & $96,67 \%$ & Very Good \\
\hline & Total & $90,09 \%$ & Very Good \\
\hline
\end{tabular}


From Table 6, it is known that the total percentage of the assessment in the small group trial from all aspects is $90,09 \%$ which is included in the assessment criteria "very good". Based on user responses (participants), this village information system-based learning model is feasible to continue in the next trial. The results of the assessment from the small group trial can also be presented in the form of a bar chart as shown in Figure 7.

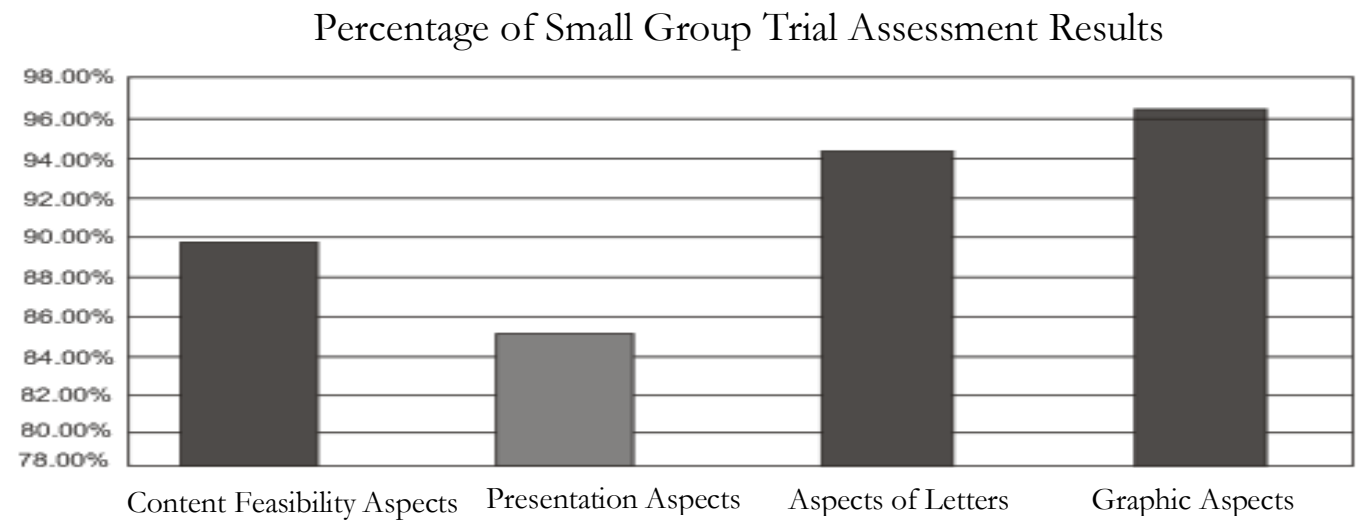

Figure 7. Bar Chart of Small Group Trial Assessment Results on Village Information SystemBased Learning Model

\section{g. Data on Tebatas Field Trial Results}

Limited field trials were carried out in villages under the auspices of the Village Community Empowerment Service in Langkat Regency. From the village, there are 20 participating village officials. The purpose of this limited field trial was to identify deficiencies in the Addcie learning model product based on the village information system that was developed after the validation stage from experts.

Table 7. Percentage of Results of Limited Field Trial Assessment of Village Information System Based Learning Model

\begin{tabular}{|c|l|c|c|}
\hline No & \multicolumn{1}{|c|}{ Assessment Indicators } & Percentage & Criteria \\
\hline 1. & Guidance and Information Aspects & $91 \%$ & Very Good \\
\hline 2. & Material Aspects of the Model & $90,50 \%$ & Very Good \\
\hline 3. & Evaluation Aspects & $92,50 \%$ & Very Good \\
\hline 4. & Design Aspects and Model Facilities & $97,50 \%$ & Very Good \\
\hline \multicolumn{2}{|c|}{ Total } & $92,08 \%$ & Very Good \\
\hline
\end{tabular}

From Table 7, it is known that the percentage of the assessment in limited field trials from all aspects is $92.08 \%$ which is included in the assessment criteria "very good". The results of this limited field trial can also be presented in the form of a stem agram as shown in Figure 8 below: 


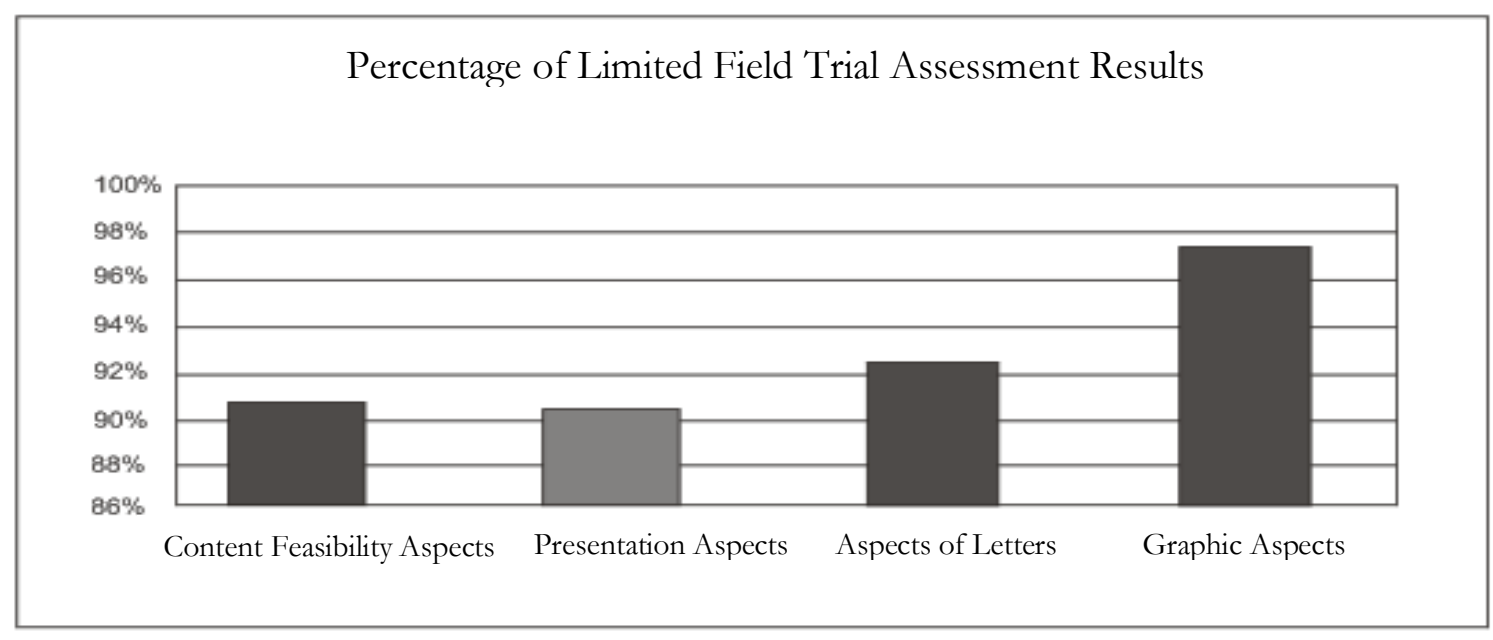

Figure 8. Bar chart of the Results of Limited Field Trial Assessment of the Village Information System Based Learning Model.

From the results of a limited field trial of 20 Village Apparatus (participants) of the Village Community Empowerment Service in Langkat Regency, it was found that in general the participants stated that the Addcie learning model based on the village information system developed had criteria of "very good" and there were no problems that had to be repaired again. Thus, there is no need for revisions at this stage of limited field trials. In other words, this village information system-based learning model is ready to be tested for its effectiveness.

\subsection{Product Revision}

Based on comments and suggestions for improvement from material experts, designs, learning models and users (participants) of the developed village information system based learning model products, the researcher revised the product. The details of the revisions are as follows:

\section{a. Revision of the Learning Model Expert}

Learning model experts suggest several improvements to the developed learning model which include: (a) clarity of the model syntax; and (b) the relevance of learning activities in the lesson plan with the syntax of the model.

\section{b. Revisions from Learning Material Experts}

Learning material experts suggest some improvements to learning media developed based on media content, which include: (a) test variations in the learning module consisting of multiple choices and other types of tests for each of the subject and sub-topic activities, (b)) Each material must have a level of difficulty, (c) shorten the duration of the village information system text to 3 minutes, and (4) make learning objectives at the beginning of the subject matter.

\section{c. Revisions from Learning Design Experts}

Learning design experts suggest several improvements to instructional media developed based on instructional media design which include: (a) titles to make them more focused and clear; (b) adding a page that explains about maximizing the learning process through the media; (c) create a glossary; (d) summarize the material; (e) add feedback to the exercise; (g) improving the typeface used in the media, (h) guidance (feedback) on the following material. 


\section{d. Revisions from Learning Media Experts}

Media experts suggest several improvements to learning media developed based on media constructs, which include: (a) clarity of voice in the text presented; (b) too short a duration of time between activity and evaluation tests, and (c) clarity of other media.

\section{e. Revisions from Users in Individual Trials}

The last revision is a revision from users based on the results of individual trials of 3 village apparatus training participants at the Village Community Empowerment Service in Langkat Regency. From the results of this individual trial, only one suggestion was found for improvements to the village information system-based Addcie learning module at the Community Empowerment Service in Langkat Regency, namely clarifying the text on the evaluation page.

From the results of small group trials and limited field trials, there were no suggestions for improvements to the Adccie learning model based on the village information system at the Village Community Empowerment Service in Langkat Regency. Thus, the research can be continued by testing the effectiveness of the developed Adccie learning model based on the village information system at the Village Community Empowerment Service in Langkat Regency.

\subsection{Product Effectiveness Test Results}

Data on learning outcomes of training participants who are taught using an Intractive Learning Model based on village information systems.

Based on the results of the participant posttest that was taught with the village information system-based learning model the lowest score was 70, the highest score was 97 , the average score was 80.70 , mode 81.64 , media 81.17 and standard deviation 7.88 . The data on the pre-test results of the training participants who were taught using the village information system-based learning model can be seen in Table 8 .

Table 8. Table of Frequency Distribution of Participant Posttest Values that are taught by the Village Information System Based Learning model

\begin{tabular}{|c|c|c|c|}
\hline No & Interval Class & $\mathrm{fi}$ & Relative Frequency $(\%)$ \\
\hline 1. & $70-74$ & 5 & 25 \\
\hline 2. & $75-79$ & 3 & 15 \\
\hline 3. & $80-84$ & 6 & 30 \\
\hline 4. & $85-89$ & 2 & 10 \\
\hline 5 & $90-94$ & 3 & 15 \\
\hline 6. & $95-99$ & 1 & 5 \\
\hline & Total & 20 & 100 \\
\hline
\end{tabular}

Based on table 8 , it is known that the percentage of the number of participants with scores is that the average is $40 \%$, the value is about $30 \%$ on average and the value is above the average, namely $30 \%$. The participant post-test data can also be described in the form of a histogram as shown in Figure 9. 


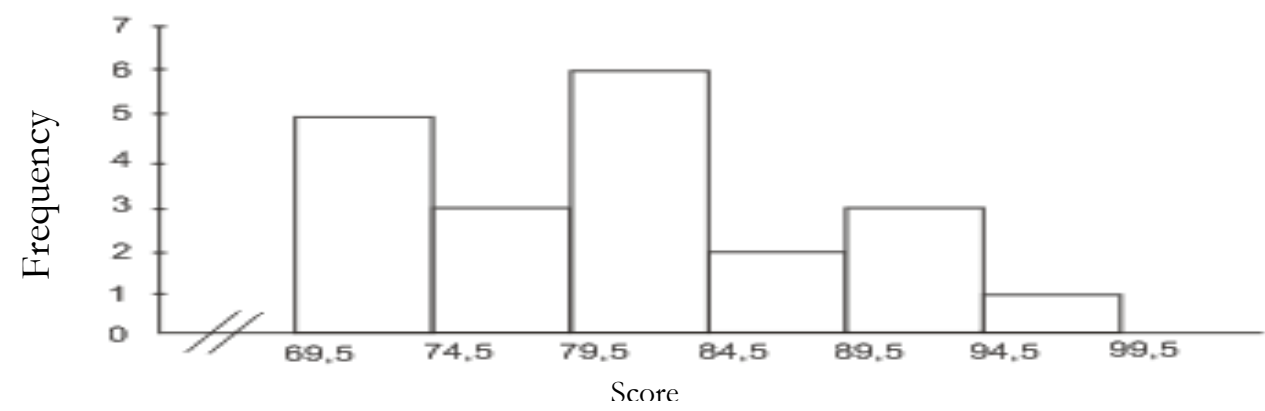

Figure 9. Learning Outcomes Data of training participants who are taught using conventional learning models

Based on the results of the participants' posttests that were taught using conventional learning models, the lowest score was 60 , the highest score was 87 , the average score was 71.95 , the mode was 71.72 , the media 72 and the standard deviation was 8.41 . The data on the results of the participants' posttests who taught the conventional learning model can be seen in table 9 .

Table 9. The Frequency Distribution Table of Participants' Post-Test Values who are taught by the Conventional Learning Model

\begin{tabular}{|c|c|c|c|}
\hline No & Interval Class & fi & Relative Frequency (\%) \\
\hline 1. & $60-64$ & 5 & 25 \\
\hline 2. & $65-69$ & 2 & 10 \\
\hline 3. & $70-74$ & 6 & 30 \\
\hline 4. & $75-79$ & 1 & 5 \\
\hline 5. & $80-84$ & 5 & 25 \\
\hline 6. & $85-89$ & 1 & 100 \\
\hline & Total & 20 & \\
\hline
\end{tabular}

Based on table 9, it is known that the percentage of the number of participants with a value below the average, namely $35 \%$, the average zither value is $30 \%$ and the value above the average is $35 \%$. The post-test data of the training participants can also be described in the form of a histogram as shown in Figure 10.

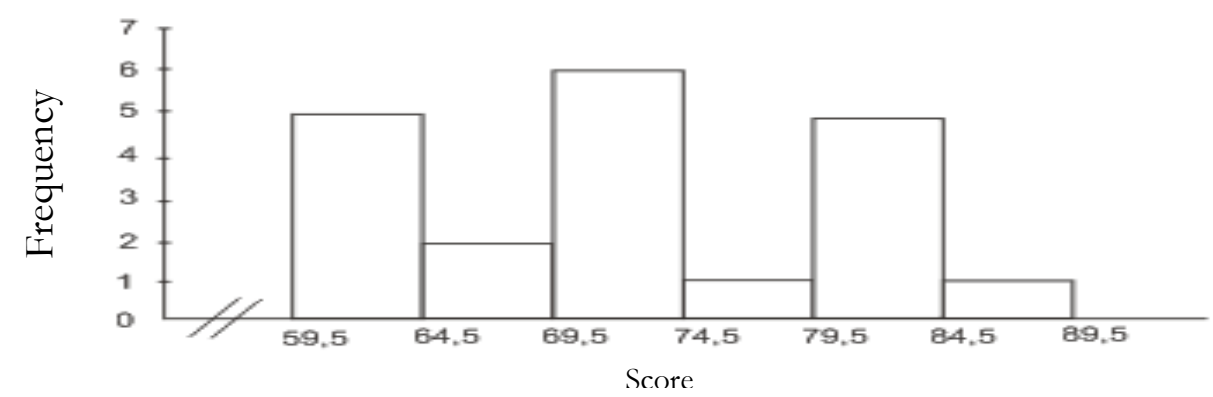

Figure 10. Histgram of Participants' Post-Test Values who are taught using the Conventional learning model 


\subsection{Test Data Analysis Requirements}

The data analysis requirements test was carried out to test the parametric statistical research hypothesis. The data analysis requirements test carried out in the study were the normality test and the homogeneity test.

\section{a. Normality Test}

The data normality test uses the Lilifors test with the null hypothesis $(\mathrm{Ho})$ which states that the sample comes from a normally distributed population. Ho acceptance and rejection is based on the comparison of the value of $\mathrm{L}$ count with the price of 1 table at the significance level a of 0.05 . If $\mathrm{L}$ count $<\mathrm{L}$ table, the data is normally distributed.

Table 10. The summary of the data normality test on the experiment and control class

\begin{tabular}{|c|c|c|c|c|c|}
\hline No & Data & Class & L count & L table & Conclusion \\
\hline 1. & Pretest & Experiment & 0,155 & 0,190 & Normal \\
\hline 2. & Pretest & Control & 0,187 & 0,190 & Normal \\
\hline 3. & Postest & Experiment & 0,186 & 0,190 & Normal \\
\hline 4. & Postest & Control & 0,149 & 0,190 & Normal \\
\hline
\end{tabular}

\section{b. Homogeneity Test}

The homogeneity test of the data uses Fisher's test. This homogeneity test is carried out to determine whether the data is homogeneous or not, which is seen based on the calculation of the F price count with $\mathrm{F}$ table at the significance level a of $0.05 \mathrm{Apb}$ if $\mathrm{F}$ count $<$ F table then the data has the same variance or homogeneous. The summary of the data homogeneity test results in the experimental class and control class can be seen in Table 11.

Table 11. The summary of the results of the homogeneity test of the data in the experimental class and control class

\begin{tabular}{|c|c|c|c|c|c|}
\hline No & Data & Class & F count & F table & Conclusion \\
\hline 1. & Pretest & Experiment & 1,17 & 2,15 & homogeneous \\
\hline & & Control & & & \\
\hline 2. & Postest & Experiment & 1,14 & 2,15 & homogeneous \\
\hline & & Control & & & \\
\hline
\end{tabular}

\section{c. Hypothesis Testing}

Hypothesis testing in this study was carried out using the $t$ test formula The $t$ test was to determine whether there was a significant difference between the learning outcomes of the development of the village apparatus capacity training model based on the village information system at the Village Community Empowerment Service in Langkat Regency (experimental class) village apparatus based on village information systems that are taught the learning model (Control). Based on the calculation results obtained $\mathrm{t}$ count $=3.44$ and table $\mathrm{t}$ table $=1.68$, so that $t$ count $>t$ table at a significant level a of 0.05 . Based on these results, Ho is rejected and $\mathrm{Ha}$ is accepted, or in other words there is a significant difference between the learning outcomes of the training participants in the control class and the experimental class at a significance level of $5 \%$. Thus, the learning outcomes of village apparatus capacity training based on village information systems at the Village Community Empowerment Service in Langkat Regency which are taught using the village information system-based learning model have a significant difference with the learning outcomes of village apparatus capacity training taught using conventional learning models. 
To test how much the value of the effectiveness of the village information systembased learning model being developed, the following calculations are carried out:

$$
\begin{aligned}
X & =\underline{\text { Total score obtained }} \\
& =\underline{\text { The sum of the ideal scores of all items }} \\
& =80,70 \% 100 \%
\end{aligned}
$$

The value of the effectiveness of conventional learning models can be seen in the following calculations:

$$
\begin{aligned}
X & =\underline{\text { Total score obtained }} \times 100 \% \\
& =\frac{1442 \times 100 \%}{2000} \times \\
& =72.10 \%
\end{aligned}
$$

Based on the calculation of the effectiveness test on the two training learning models, the results show that the learning outcomes of village apparatus capacity training based on village information systems at the Village Community Empowerment Service in Langkat Regency are higher than conventional learning outcomes $(80,70 \%>72.10 \%$ ) With these results, it can be concluded that the learning model based on the village information system is more effective in learning the development of the village apparatus capacity training model based on the village information system at the Village Community Empowerment Service in Langkat Regency compared to using conventional learning.

\section{Conclusion}

1. The Addcie learning model is a collaborative integration of six active training models that can be used as a learning model at the Village Community Empowerment Service in Langkat Regency. And training for village apparatus capacity skills. The Addcie learning model has elements of the learning model syntax, there are six steps, namely: Analysis, Design, Development, Coundact, Implementation, Evaluation (initial step) Analysis (analyzing the training needs of village apparatus capacity and DUDI characteristics) Design, Development (subject matter) based Village information system (Attitude Skills) Implementation and evaluation (skill application) of village information systems in the field) at each syntax step that is owned by the Addcie learning model has elements of a social system between the capacity of village officials and participants, facilitators and the capacity of village officials, DUDI With the capacity of village apparatus with skills and community and training participants, the principle of the Addcie learning model reaction is that village apparatus participants carry out active activities during learning where the capacity of the village apparatus as producers of the Addcie learning model The role of the facilitator acts as a hli who guides as a facilitator who is assisted by other supporting facilities and infrastructure. This Addcie learning model can run optimally with the availability of facilities, the number of training participants for the capacity of village apparatus in the classroom and has other supporting media as a support system for the implementation of Addcie learning, the capacity of system-based village apparatus village information at the Village Community Empowerment Agency in Langkat Regency. So that the visible accompanying impact is the capacity of village officials, responsibility and confidence in competing in the world of business and industry as well as the ability to work and innovate. 
2. The product of a village information system-based learning model developed in learning the capacity of village officials for the capacity of village officials at the Village Community Empowerment Service in Langkat Regency. This can be concluded based on the results of the assessment of learning material experts at $82.94 \%$, media experts by $85 \%$, individual trials at $81.03 \%$, group trials at $90,09 \%$ and limited field trials at $92.08 \%$. Overall the results of the experts' assessment and testing of usage stated that the village information system-based learning model was in the criteria of "very good".

3. The use of the developed village information system-based learning model is considered to be more active in increasing the competency of the village apparatus that has been developed is considered to be more effective in increasing the competency of the Village Community Empowerment Service in Langkat Regency. Compared with using conventional learning models. It can be concluded that based on the results of the training on the capacity of village officials who are taught using the village information system based learning model is higher than the learning outcomes of the village apparatus capacity taught using conventional learning models $(80.70 \%>72.10 \%)$.

\section{References}

Anderson, L.W. dan Krathwohl, D.R. (2001). A Taxonomy for Learning,Teaching, and Asessing: A Revision of Bloom's Taxonomy of EducationalObjectives. A Bridged Edition. New York: Addison Wesley Longman, Inc.

Angelia, N., at al. (2020). Analysis of Community Institution Empowerment as a Village Government Partner in the Participative Development Process. Budapest International Research and Critics Institute-Journal (BIRCI-Journal), 1352-1359.

Atwi, Suparman. (2010). DesainPembelajaran( Program Study TehnologiPendidikan Program PascaSarjana,) Universitas Negeri Jakarta. (UNJ)

Avolio, B., \& Gardner, W. (2005). Authentic leadership development: Getting to the root of positive forms of leadership. Leadership Quarterly, 16(3), 315-338.

Berger, P. (2011). Adventures of an Accidental Sociologist: How to Explain the World Without Becoming aBore. Amherst, NY: Prometheus Books.

Borg, W,R; Gall, M,D. (2007). Educational research an introduction. New York: Longman.

Charles M. Reigeluth. (2009). Intructional-Design Theories and Models Buiding A Common Knoledge Base, Volume III,Alisan a car- chelman, Taylor. Newyork and London.

Dick dan Carey. (2005). The Systematic Design Instruction. Pearson. Boston

Dinas Infokom. (2018). Materi Pelatihan Sistim Informasi Desa, Open SID.

Edwin. B. Lippo. (2007). PendidikandanPelatihan. Jakarta: RinekaCipta.

Evaluating Capacity Development; Experiences from Research and Development Organizations around the world. Netherlands-Canada: ISNAR, IDCR, ACPEU, CTA.

Grindle. (1997). Capacity Human Resourse DevelopmentNew Jersey: Prentice Hall.

John. W.Cress well. (2013). Research Design, Pendekatan Kualitatif, Kwantitatif dan Mixed, Pustaka Pelajar Celeban Timur. Yoyakarta.

Kaswan. (2011). Pelatihan dan Pengembangan Untuk Meningkatkan Kerja SDM, Penerbit Alfabeta Bandung

Matrozet, Nurwani. (2019). Sentimental Values in Tor-Tor Parsiarabu in Tomok Toba Samosir Village. Budapest International Research and Critics Institute-Journal (BIRCI-Journal), 167-171.

Morrison.Ros.Kemp. (2007). Desing effective instruction 5 th edition with contribution from hawork K. Kalma Ithaca Collage.

Morrison, Terrence. (2000). Actionable Learning; A Handbook for Capacity BuildingThrough Case Base Learning. Asian Development Bank Institute Sackney, Larry., Walker D 
Mustafa Kamil. (2007). Model PendidikandanPelatihan (KonsepdanAplikasi) ,Penerbit Alfabeta Bandung.

Nuraflah, C. A. (2020). The Communication Strategy of Government in Bulu Cina Village towards Prosperous Village. Britain International of Humanities and Social Sciences (BIoHS) Journal, 2685-3868.

Samuel, Oto Natalia. (2009). The Capacity Development Results Framework (CDRF), New Delhi: I.K. International Publishing House Pvt. Ltd.

Santoso, Bambang, Dr. (2012), Capacity Building,Bandung: Sinar Baru Algensindo.

Shoimin. (2014). Model Pembelajaran Innovatif dalam Kurikulum 2013. Yogyakarta.Ar-Ruzz Media.

Stanislaw Wryeza, Jacek Maslan kowski (Eds). (2018). Information Systems: Research, Development, Application, Education. Springer.

Sudijono. A. (2012). Pengantar Evaluasi Pendidikan. Jakarta: PT. Raja Grafindo Persada.

Sudirman. (2014). ManajemenPelatihan, Penerbit ,Unimed Press, Medan.

Walter Dick, Lou Carey. (2001). The Systemic Design of Instruction. United State: AddisonWesley Educational Publishers Inc. 